\title{
KONSEP PENDIDIKAN ISLAM PERSPEKTIF MAHMUD YUNUS
}

\author{
Bunyamin \\ Program Studi Pendidikan Agama Islam, Universitas Muhammadiyah Prof. Dr. HAMKA \\ Jakarta \\ Email : bunyamin@uhamka.ac.id, HP:0815-9555-003
}

\begin{abstract}
The condition of Islamic education in Indonesia has existed since the Dutch colonial period, especially Islamic education is in a very dwarf condition that is not yet able to contribute to the progress of the nation. This happens due to the narrow mindset of the community in interpreting the verses of the Qur'an. In addition, there is discrimination by the colonialists against Islamic education. Education established by new Muslims around Islamic boarding schools which are considered unable to meet the demands of the times. This research focuses on the concept of Islamic education according to Mahmud Yunus by using qualitative research, content analysis approaches that examine historical, textual, and comparative approaches. Findings from the results of this study according to Mahmud Yunus, education is more specialized in moral education than the objectives of Islamic education, in the process of learning that places priority over methods. Thus the researcher is able to conclude about the concept of Islamic education from Mahmud Yunus from the objectives, methods, institutions, systems, and curriculum that really gives a great influence on Islamic education in Indonesia.
\end{abstract}

Keywords: Islamic Education, Arabic Language, Science, Methode.

\begin{abstract}
Abstrak
Kondisi pendidikan Islam di Indonesia telah ada sejak masa kolonial Belanda, khususnya pendidikan Islam berada dikondisi yang sangat kerdil yakni belum dapat memberikan kontribusi terhadap kemajuan bangsa. Hal ini terjadi akibat pola fikir masyarakat yang sempit dalam mengartikan ayat-ayat Al-Qur'an. Selain itu, disebabkan juga karena adanya diskriminasi oleh penjajah terhadap pendidikan Islam. Pendidikan yang didirikan oleh umat Islam baru seputar pondok pesantren yang dianggap belum dapat memenuhi tuntutan perkembangan zaman. Penelitian ini fokus pada konsep pendidikan Islam menurut Mahmud Yunus dengan menggunakan penelitian kualitatif, pendekatan analisis konten isi yang mengkaji tentang pendekatan sejarah, tekstual, dan komparatif. Temuan dari hasil penelitian ini menurut Mahmud Yunus lebih mengkhususkan pada pendidikan akhak dari tujuan pendidikan Islam, dalam proses
\end{abstract}


pembelajaran lebih mengutamaan metode dibandingkan dengan materi. Dengan demikan peneliti mampu menyimpulkan mengenai konsep pendidikan Islam dari Mahmud Yunus dari tujuan, metode, kelembagaan, sistem, serta kurikulum itu sangat memberikan pengaruh yang besar terhadap pendidikan Islam di Indonesia.

Kata Kunci : Pendidikan Islam, Bahasa Arab, Pengetahuan Umum, Metode.

\section{PENDAHULUAN}

Sebuah proses pembelajaran harus memiliki sebuah tujuan, di mana tujuan pembelajaran harus seiring dengan tujuan pendidikan dalam Undang Republik Indonesia No. 20 Tahun 2003 yang berbunyi: "Untuk berkembangnya potensi agar menjadi manusia yang beriman dan bertakwa kepada Tuhan Yang Maha Esa, berakhlak mulia, sehat, berilmu, cakap, kreatif, mandiri dan menjadi warga Negara yang demokratis serta bertanggung jawab". Pendidikan di Indonesia sangat memprioritaskan dan mendapatkan perhatian yang besar khususnya bagi penyelenggra pendidikan seperti guru dan peserta didik sebagai subjek dan objek dalam pembelajaran. Tugas guru yang profesional di antaranya memiliki 4 komoetensi guru yaitu kompetensi kepribadian hal ini terkait dengan tampilan dari seorang guru, tutur kata, cara berpakaian dan tingkah laku guru, kopetensi sosial di mana guru hasru bisa bersosialisasi dan beradaptasi dengan sesama, kompetensi pedagogik yaitu menguasai konsep keguruan seperti menguasai bahan ajar, metode pembelajaran dan lain-lain, serta kompetensi professional di mana guru harus menguasai materi yang ingin disampaikan. Guru dikatakan professional yakni dengan memberikan seluruh kewajibannya dan seluruh hak dari peserta didik itu sendiri.

Dalam dunia pendidikan, Integrasi keilmuan pada lembaga pendidikan menjadi pokok pemikiran yang penting dalam menjalankan sebuah proses pembelajaran. Integrasi keilmuan masih terdapat beberapa kendala salah satu contohnya pada saat berjalannya interaksi edukatif atau yang lazimnya di dengar dengan proses belajar mengajar, tugas seorang guru menjadi administrator, evaluator, konselor dan sebagainya. Dalam hal ini guru menjadi peran utama demi tercapainya sebuah proses pembelajaran. Dengan adanya sosok seorang guru dapat memberikan perubahan pada misi pendidikan. Mereka menjadi titik sentral dalam mengatur sebuah proses pembelajaran, mengarahkan dan menciptakan 
suasana agar tercipta proses interaksi yang edukatif untuk tercapainya tujuan pendidikan yang diinginkan. Oleh karena itu, pendidik dituntut untuk lebih profesional, inovatif, perfektif, dan proaktif dalam menjalankan proses belajar mengajar.

Pendidikan menurut bahasa Arab dikenal dengan istilah Ta'lim, Ta'dib, Tarbiyah, Irsyad, Tadris, dan Riyadiyah, (Mujib dan Mudzakkir, 2006). Walaupun banyak istilah pendidikan yang mendefinisikan tentang pendidikan, akan tetapi tujuan dari pendidikan Islam yaitu memiliki pengertian yang sama untuk membentuk karakteristik peserta didik yang sesuai dengan harapan.

Baik pendidikan ataupun pengajaran dalam proses kegiatan belajar mengajar akan lebih sempurna jika ditanamkan pendidikan akhlak, pendidikan jasmani, pendidikan perasaan, pendidikan masyarakat, pendidikan pribahasa, dan lain sebagainya. Dengan pendidikan yang sempurna, maka tercapailah pendidikan yang membentuk insan kamil. Ada beberapa kebutuhan yang dibutuhkan untuk tercapai kepada insan kamil, yakni dengan berakal sehat dan bertubuh kuat, dalam pribahasa "akal yang sehat terdapat pada tubuh yang kuat". Maksudnya ketika akal kita berfungsi dengan baik, dapat berfikir secara rasional dan sistematis, secara otomatis badan kita masuk dalam kategori tubuh yang sehat.

Seorang pendidik tidak akan dapat menjalankan proses belajar mengajar dengan baik tanpa mengetahui perkembangan jasmani dari peserta didik tersebut. Dengan ini kesehatan dari setiap peserta didik sangat diutamakan dalam proses belajar mengajar dan agar akal yang akan digunakan dalam proses penerimaan pengetahuan dari pendidik dapat diterima secara maksimal.

Sejalan dengan tujuan pendidikan Nasional berdasarkan Undang-Undang, dapat direfleksikan bahwa pendidikan akhlak menjadi perhatian yang penting dan menjadi prioritas dalam proses pembelajaran di mana guru dapat membentuk karakter/sikap yang baik bagi peserta didik untuk menciptakan generasi yang santun dan religius. Dengan akhlak yang baik, maka pendidik akan lebih mudah menanamkan sifat-sifat baik seperti, jujur, ikhlas, menepati janji, menunaikan kewajiban dan lain sebagainya.

Proses pada Kegiatan belajar mengajar merupakan aspek yang dapat terlihat di lingkungan sekolah yang terorganisir, berperan penting dalam proses belajar mengajar adalah lingkungan (Assegaf, 2010). Lingkungan ini di atur untuk kegiatan interaksi 
edukatif ini berjalan sesuai apa yang diharapkannya dengan tujuan pendidikan. Proses belajar mengajar adalah tujuan utama dari kegiatan belajar di sekolah antara pendidik dan peserta didik. Maka setiap pendidik mengambil kesempatan di dalam proses interaksi edukatif untuk menanamkan pendidikan Islam, mentransformasi nilai-nilai kebudayaan Islam ke dalam pribadi peserta didik. Hal ini akan membuat peserta didik memiliki akhlak yang baik, beriman, dan bertaqwa kepada Allah SWT. sebagaimana dalam QS. Al-Maidah: 35, yang berbunyi:

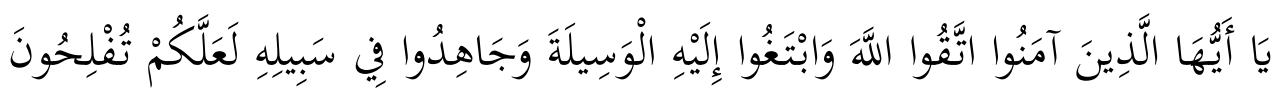

Artinya :

"Hai orang-orang yang beriman, bertakwalah kepada Allah dan carilah jalan yang mendekatkan diri kepada-Nya, dan berjihadlah kepada jalan-Nya, supaya kamu mendapatkan keberuntungan" (QS. Al-Maidah: 35)

Dilihat dari sejarahnya,pendidikan Islam berkembang pesat melaui kegiatan dakwah Islamiah di mana penyampaian risalah keislaman tidak lepas dari perjuangan para pedagang Gujarat India. Para pedagang Gujarat selaian tujuan mereka untuk berdagang, mereka menyisipkan misi yaitu dalam upaya menyebarluaskan agama islam ke masyarakat di Indonesia.

Dalam menentukan sumber-sumber pendidikan Islam, tidak lepas dari kurikulum Pendidikan Islam di mana proses kegiatan belajar mengajar yang di dalamnya terdapat materi pembelajaran, metode pembelajaran, media, sarana, dan evaluasi dalam pembelajaran. Evaluasi pembelajaran dijadikan sebagai standar dan tolok ukur dalam sebuah pembelajaran untuk mengetahui sejauh mana harapan serta tujuan yang diinginan oleh sebuah pendidikan.

Metode pendidikan Islam merupakan sebuah prosedur umum dalam menginformasikan ilmu Islam untuk mencapai tujuan yang didasarkan atas asumsi tentang hakikat Islam sebagai suprasistem (Mujib dan Mudzkir, 2010). Fungsi sebuah metode 
pendidikan yakni sebagai inspirasi pada peserta didik dengan hubugan yang serasi atau singkron antara peserta didik dan pendidik yang seiring dengan tujuan pendidikan.

Seorang tokoh pendidikan Islam yaitu Mahmud Yunus merumuskan dan mengembangkan terkait dengan pendidikan Islam di mana pendidikan islam mengacu pada komitmen dan keinginan yang tinggi dalam upaya mengembangkan, membangun dan meningkatkan kualitas pendidikan Islam sebagai integral sistem pendidikan Islam untuk masyarakat Indonesia dan khususnya umat muslim.

Dilihat dari tujuan pendidikan Islam, Mahmud Yunus ingin mengembangkan dunia pendidikan Islam setara dengan pendidikan umum lainnya. Peserta didik baik lulusan sekolah umum maupun sekolah berbasis pendidikan Islam memiliki kemampuan yang seimbang di mana pendidikan Islam mempunyai beberapa kelebihan lainnya. Kelebihan yang dimiliki oleh lulusan pendidikan Islam selain memiliki pengetahuan, keterampilan, dan pengalaman di dunia lainnya. Dengan demikian peserta didik berbasis pendidikan Islam memiliki dua kebahagiaan, yakni kebahagiaan di dunia dan kebahagiaan di akhirat.

Namun belakangan ini, masyarakat menilai pendidikan sangat jauh dari harapan. Melihat peserta didik yang kurang memahami makna pendidikan yang diterimanya. Pendidikan Agama yang dikenal sangat jauh tertinggal dibandingkan dengan pendidikan umum. Program-program instruksional yang membuat siswa kurang dapat belajar dengan baik. Hal seperti ini sangat membutuhkan perhatian yang khusus untuk mengembalikan pendidikan agama yang sesuai dengan harapannya, apalagi dijaman ini pendidikan jauh lebih modern dengan teknologinya sehingga mendorong pendidik untuk lebih mengerti dari peserta didik.

Pendapat Mahmud Yunus dalam kitabnya at-Tarbiyat wa at-Ta'lim guru harus profesional, dalam artian guru harus mampu memahami dan mengukur kemampuannya, mampu membuat perencanaan pembelajaran, senantiasa memperbarui pengetahuannya, sehingga mampu memberikan wawasan yang luas untuk siswa (Safiq dan Salamah, 2019). Kesadaran guru untuk itu ternyata belum begitu nampak. Penelitian Fahdini et.al (2014) menunjukan bahwa kompetensi professional guru tersertifikasi di kabupaten Sumedang, empat aspek berada pada kategori 'cukup' dan satu aspek berada pada kategori 'kurang'. Hasil analisis skala sikap dengan menggunakan program SPSS 16 menunjukan bahwa pada 
umumnya guru tersertifikasi di kabupaten Sumedang tergolong pada kategori 'baik', namun kondisi ini masih jauh dari kategori 'profesional'.

Hasil penelitian yang sama juga diperoleh Pujiastuti, Raharjo dan Widodo (2012) menyatakan bahwa kompetensi profesional dan kompetensi pedagogik guru IPA berada pada kategori rendah. Kompetensi profesional guru IPA secara langsung dan signifikan mempunyai kontribusi terhadap hasil belajar sebagai persiapan ujian nasional IPA sebesar $54,5 \%$.

Pendidik juga harus lebih paham dalam pendidikan keIslaman nya, sehingga pendidik mampu memperhatikan peserta didik mulai dari perkembangan sosial, spiritual dan emosional nya. Bentuk seperti ini hanya dapat terjadi kepada pendidik yang memiliki keterampilan mengajar yang kreati, efektif dan menarik.

Tujuan peneltian ingin memberitahu masyarakat di luar sana bahwa ada banyak sosok tokoh yang sangat berpengaruh terhadap dunia pendidikan Islam, dan pada kesempatan ini penulis mengambil Konsep Pendidikan Mahmud Yunus untuk penulis kembangkan khususnya di lembaga pendidikan pesantren yang mana konsep serta kurikulum.

\section{METODE}

Penelitian ini menggunakan metode penelitian kualitatif (qualitative research) dengan melakukan metode analisis dokumen atau sering disebut dengan analisis isi (content analysis).

\section{Analisa Data}

Dalam melakukan analisis data fokus pada pemikiran Mahmud Yunus tentang Konsep Pendidikan Islam, dilakukan analisis fokus pada istilah-istilah tertentu yang membutuhkan pemahaman secara mendalam atau konsepsional, demi mendapatkan pemahaman yang jauh lebih baik tentang Konsep Pendidikan Islam Mahmud Yunus dalam kaitannya dengan problematika pendidikan era modern saat ini.

\section{HASIL DAN PEMBAHASAN}


Ada beberapa pemikiran Mahmud Yunus terkait dengan pendidikan Islam. Beliau menyajikan beberapa nasihat bagi para pendidik di antaranya yaitu hendaklah para pendidik memiliki jiwa yang tulus untuk memposisikan dirinya menjadi seorang pengajar, hendaklah guru memiliki hobi dalam menggali dan mencari sebuah informasi agar pendidik memiliki pengetahuan yang luas dan mendalam dalam penguasaan keilmuannya sehingga dalam proses pengajaran dapat ditransfer secara maksimal.

Selain itu, seorang pendidik harus pandai dalam bergaul dan berkomunikasi dengan lingkungan sekitar, dapat membawa diri dalam berinterasi dengan yang lain, saling menghargai dan menghormati. Seorang pendidik dapat jadi suri teladan yang baik agar bisa dicontoh untuk peserta didiknya. Hal ini dapat terlihat dari perilaku, tutur kata, cara berpakaian yang sopan dan menutup aurat sesuai dengan ketentuan Islam. Karena guru itu diguguh dan ditiru oleh peserta didik. Pendidik harus memiliki akhlak dan adab tertib sopan yang tinggi, terutama dihadapan murid-muridnya.

Dalam penyampaian dan berkomunikasi dengan peserta didik, seorang guru harus bisa memilah dan memilih kata-kata yang ingin diucapkan disesuaikan dengan usia mereka. Oleh sebab itu, pendidik perlu menurunkan derajat fikirnya disesuaikan dengan perbedaan dari keberagaman peserta didiknya, perasaannya, khayalnya, supaya dapat menyesuaikan dan menyelaraskan mereka dengan pola pikir dan perasaan yang sama dengan peserta didiknya.

Selanjutnya Mahmud Yunus menganjurkan kepada guru agar dalam penyampaian materi pada proses pembelajaran harus bermakna, menjelaskan manfaat atau faedah dari masing-masing ibadah yang diajarkan kepadanya. Sebagai contoh dalam ibadah sholat, seorang guru harus bisa menjelaskan ketentuan-ketentuan tentang sholah dan tata cara sholat serta dapat menjelaskan manfaat dari pelaksanaan sholat tersebut, di mana dalam pelaksanaan sholat yang benar itu terdapat manfaat kesehatan aliran darah menjadi lancar dan lain-lain, jadi integrasi pengetahuan dapat diberikan secara maksimal.

Dari segi tujuan pendidikan Islam, Mahmud Yunus menegaskan harus ada perbedaan dari lulusan yang dihasilkan dari lembaga pendidikan Islam dengan lembaga pendidikan umum. Menurutnya, lulusan pendidikan Islam harus lebih baik mutunya dari lulusan sekolah-sekolah lainnya.. 
Tujuan yang demikian itu, menurutnya masih belum maksimal, karena dianggap masih belum sempurna. Mahmud Yunus menyimpulkan bahwa tujuan pendidikan Islam adalah menyiapkan anak-anak didik bisa berkompetitif dan berkompetensi dalam urusan dunia dan akhirat di mana konsep seimbang antara ilmu akhirat dan ilmu dunia. Mampu memahami dan melakukan pekerjaan dalam urusan dunia dan akhirat. sehingga tercipta kebahagiaan bersama dunia akhirat (Nata, 2005).

Berkaitan dengan tujuan pokok pendidikan Islam, Mahmud Yunus lebih lanjut merumuskannya adalah sebagai berikut: pertama, untuk mencerdaskan perseorangan yang dimaksud adalah mencerdaskan peserta didik dalam hal penguasaan materi (konseptual), kedua, kompetensi yang dimiliki peserta didik yaitu dalam hal kecakapan mengerjakan pekerjaan/keterampilan (softskill).

Menurut pendapatnya, ia kurang menyetujia terkait degan pendapat ulama tradisional yang mengatakan bahwa tujuan pendidikan Islam hanyalah untuk beribadah dan sekedar mempelajari agama Islam saja. Menurutnya, beribadah itu merupakan salah satu perintah Islam, di mana itu kaitannya dengan hubungan manusia kepada Tuhannya (Hablumminallah) Sedangkan pekerjaan duniawi sejalan dengan hubungan dengan sesame manusia (hablumminannas) yang tercermin dalam pergaulan dengan sesama makhluk dan merupakan bentuk peribadatan kepada Tuhan yang merupakan perintah Islam (Nata, 2005).

Dengan demikian, pekerjaan duniawi termasuk juga tujuan pendidikan Islam. Selain itu, Mahmud Yunus menekankan pada tujuan pendidikan Islam di mana bahwa tujuan pendidikan harus lebih memprioritaskan pada pendidikan akhlak hal ini sejalan dengan diutusnya Nabi Muhammad SAW di muka bumi sesuai dengan hadits rasul yang berarti sesungguhnya Aku diutus ke muka bumi untuk memperbaiki akhlak dan budi pekerti umat manusia.

Atas dasar pemikiran tersebut di atas, Mahmud Yunus mencetuskan bahwa tugas yang utama dan pertama bagi para mu'allim dan para para ulama, guru-guru agama dan pemimpin-pemimpin Islam adalah mendidik anak-anak, para pemuda, putra-putri orangorang dewasa dan masyarakat umumnya, dengan tujuan agar mereka memiliki akhlak yang mulia dan berbudi pekerti mulia. Karena dengan membenahi dan menanamkan akhlak yang 
baik, maka akan baik pula segalanya. Hal yang demikian tidak berarti bahwa pendidikan jasmani, adil dan amal tidak dipentingkan sama sekali, tetapi yang menjadi prioritas dalam tujuan pendidikan lebih menekankan pada pendidikan Akhlak. (Nata, 2005).

Berdasarkan uraian di atas dapat diketahui bahwa tujuan pendidikan Islam adalah mendorong seseorang agar mengamalkan ajaran Islam secara sempurna, yaitu menyeimbangkan ilmu agma dan ilmu dunia, yaitu dengan menjalankan ajaran secarat utuh dan menyeluruh sehingga seseorang tidak hanya menguasai pekerjaan-pekerjaan yang bersifat ukhrawi, tetapi pekerjaan yang bersifat duniawi dan dihiasi dengan akhlak yang mulia, sehingga tercapai kebahagiaan hidup yang seimbang. Hal ini sejalan dengan hadits nabi yang berarti "barang siapa yang mencari/mengejar urusan dunia maka harus diiringi dengan ilmu, dan barang siapa yang mencari urusan akhirat maka harus diiringi dengan ilmu pula. Hal ini terlihat jelas konsep keseimbangan tentang ilmu dunia dan ilmua akhirat.

Jadi tujuan pendidikan Islam, menurut Mahmud Yunus adalah menyiapkan anak didik agar diwaktu dewasa kelak mereka cakap melakukan pekerjaan dunia dan amalan akhirat, karena konsep keseimbangan dengan tidak membedakan porsi ilmu agama dan ilmu umum sehingga tercipta kebahagiaan bersama dunia akhirat. Agar anak didik mampu melaksanakan amalan akhirat, anak-anak harus dibekali dan ditanamkan tentang konsep keimanan, akhlak, ibadah, dan isi-isi Al Quran yang berhubungan dengan sesuatu yang wajib dikerjakan dan yang haram dan harus ditinggalkan. Hal ini sejalan dengan konsep takwa yaitu menjalankan segala perintah-Nya dan menjauhi segala larangan-Nya.

Dalam hal kompetensi keterampilan peserta didik, agar anak didik cakap dalam melaksanakan pekerjaan dunia, mereka harus dididik untuk mengerjakan salah satu dari macam-macam profesi, seperti: bertani dengan mengajarkan langsung tata cara bercocok tanam, mengimplementasikan langsung tentang konsep berdagang, diajarkan bagaimana membuat sebuah tendan untuk berkemah, bertukang, menjadi guru dan lain-lainnya sesuai dengan bakat dan bawaan masing-masing anak didik (Arief, 2006).

Mahmud Yunus memiliki gagasan yang baru pada masa itu dan dianggap masih relevan untuk masa sekarang jika digunakan dan diimplementasikan dalam lembaga pendidikan. Berkaitan dengan kurikulum pengajaran bahasa Arab, Mahmud Yunus menawarkan kurikulum pelajaran bahasa Arab yang integrated antara satu cabang dengan 
cabang yang lainnya dalam ilmu bahasa Arab. Seorang anak didik diberikan cabang-cabang ilmu bahasa Arab yang dipadukan dengan menerapkannya dalam pergaulan hidup seharihari (Nata, 2005). Sebagai contoh pembelajaran bahasa arab dapat diintegrasikan dengan ilmu komunikasi, dimana di dalamnya terdapat gaya bahasa, intonasi dan pelafalan dalam kosa kata.

Dalam konteks kompetensi amaliyah akhirat, anak didik diberi kecakapan dalam mengerjakan amalan-amalan akhirat yaitu peserta didik diajarkan pelajaran tauhid, akhlak, ibadah, sejarah islam dan pokok-pokok ajaran yang terkandung dalam Al-Quran mengenai hukum halal, haram. Karena dengan diberikan materi tersebut, peserta didik dapat membedakan mana makanan yang halal atau makanan yang haram, atau perbuatan yang baik maupun perbuatan yang buruk.

Pada dasarnya manusia mempunyai banyak kecenderungan, yaitu, kecenderungan menjadi orang yang baik dan kecenderungan menjadi orang yang jahat, sedangkan kecenderungan beragama termasuk kecenderungan manusia yang terbaik (Tafsir, 2001). Contoh kecenderungan menjadi orang baik manusia menampilkan dan menunjukkan segala sisi positif dalam mengaktualisasikan dirinya pada perbuatan yang baik begitupun sebaliknya.

Meski demikian, dari kesemua materi pelajaran yang diberikan kepada anak didik. Mahmud Yunus sangat menekankan pentingnya pendidikan akhlak, mengingat diutusnya Rasulullah SAW kedunia untuk menyempurnakan akhlak manusia (Wahab, 2004) maka menurut Mahmud yunus tugas pertama dan utama para ulama, guru-guru agama Islam, pemimpin-pemimpin Islam adalah mendidik anak-anak, pemuda-pemudi, calon penerus generasi bangsa dan masyarakat umumnya supaya mereka berakhlak mulia dan berbudi pekerti luhur. Hal ini bukan berarti mengabaikan pendidikan lainnya (pendidikan jasmani, aqali, dan amali).

Pendangan Mahmud Yunus yang demikian itu memperlihatkan bahwa konsep yang dirumuskan dan disosialisasikannya itu benar-benar menyeluruh yaitu mencakup aspek kognitif, psikomotorik dan afektif. Pada aspek kognitif, Mahmud Yunus lebih menekankan pada pendalaman materi untuk membawa murid berfikir secara kritis, sehingga para siswa dapat menggunakan penalarannya semaksimal mungkin. Aspek psikomotorik, Mahmud 
Yunus menekankan pada pengembangan kecakapan murid, selain cerdas itu juga mampu mengaplikasikan ilmu yang dipelajarinya di masyarakat, sedangkan aspek afektif Mahmud Yunus menekankan pentingnya seorang guru menanamkan moral kepada murid (Nata, 2005). Dengan kata lain, Mahmud Yunus tidak menghususkan pada satu aspek saja/ mendominasikan aspek kognitif dalam proses pembelajaran tetapi ia mendesain harus mencakup 3 ranah tersebut agar tujuan dapat maksimal dalam proses pembelajaran.

Secara rinci Mahmud Yunus merumuskan tujuan pendidikan agama di sekolah umum pada tiap tingkatnya sebagai berikut:

a. Menanamkan perasaan cinta dan taat kepada Allah dalam hati anak-anak, yaitu dengan mengingatkan pada nikmat dan rahmat Allah yang tak terhitung banyaknya. Proses penanaman kecintaan kepada Allah merupakan hal yang utama yang harus dilakukan karena dengan membentuk kecintaan pada Tuhannya, maka peserta didik dapat meresapi bahwa dirinya merupakan makhluk ciptaan-Nya yang harus menghamba pada-Nya.

b. Menanamkan itikat yang benar dan kepercayaan yang betul dalam hati anak-anak. Hal ini penting karena penanaman konsep terkait dengan kepercayaan merupakan bentuk tauhid yang harus dimiliki oleh masing-masing setiap individu. Dengan menyakini bahwa Allah adalah tuhan kita, maka peserta didik dapat memahami konsep keberadaan Tuhan.

c. Mendidik anak agar tekun melaksanakan perintah Allah dan menjauhi larangannya. Hal ini sejalan dengan esensi dari diciptakannya manusia ke muka bumi yaitu untuk bertakwa dengan menjalankan segala yang diperintah-Nya dan menjauhi segala larangan-Nya.

d. Membiasakan anak didik supaya berakhlak mulia. Karena dengan pembiasaan maka peserta didik akan terbiasa bersikap dan menampilkan sikap-sikap yang baik (bertutur kata yang sopan, saling menghargai dan lain-lain)

e. Mendidik agar anak-anak mengetahui cara-cara melaksanakan ibadah sehari-hari dengan benar. Hal ini penting karena pelaksanaan peribadatan memang ada tata-caranya sesuai dengan ketentuan yang telah ditetapkan.

f. Membimbing anak supaya mempersiapkan diri untuk kehidupan dunia dan akhirnya. Hal ini sesuai dengan konsep keseimbangan antara ilmu dunia dan ilmu akhirat. 
g. Memberikan contoh dan suri tauladan yang baik. Pendidik harus dapat memberikan contoh bagi anak didiknya, karena pendidik merupakan sosok yang dijadikan sebagai panutan bagi mereka.

h. Membina dan mendidik anak supaya menjadi warga negara yang baik, sehingga bisa hidup bergaul dengan baik di tengah-tengah masyarakat (Yunus, 1992).

Dalam masalah kurikulum Mahmud Yunus merefleksikan keseimbangan antara ilmu pengetahuan agama dan ilmu pengetahuan umum, yang selama ini belum dikenal madrasah tradisional. Hal ini dapat diliat di kurikulum Normal Islam Padang terdiri dari ilmu Agama, Bahasa Arab (Insya', Muthola'ah, Mahfudzot, Adabul Lughoh, Qowaid), Ilmu Umum (Aljabar, Ilmu Hukum, Ilmu Alam, Ilmu Hayati, Ekonomi, Tarikh Islam, Sejarah Indonesia, Ilmu Bumi, Tata Negara, Bahasa Inggris, Ilmu Pendidikan, Ilmu Jiwa, Ilmu Kesehatan, Khat / Menggambar) (Ramayulis dan Nizar, 2005). Dalam kurikulum ilmu agama tidak dirincikan, akan tetapi didalam kehidupan nyata dirinci menjadi, tafsir, hadist, fiqh atau ushul fiqh.

Kurikulum Normal Islam lebih memprioritaskan ilmu Pengetahuan Umum dibandingkan dengan ilmu Pengetahuan Agama dan Pengetahuan Arab, kemudian alokasikan waktu yang diberikan untuk ilmu pengetahuan Agama hanya 15\%, bahasa Arab $20 \%$ dan $65 \%$ waktu yang tersedia untuk mentransformasikan ilmu-ilmu umum.

Menurut Mahmud Yunus semua mata pelajaran baik pengetahuan agama maupun pengetahuan umum bermuara pada tujuan pendidikan Islam, yaitu membentuk Insan Kamil yang taqwa kepada Tuhan, cerdas, cakap, tampil, tangkas, dan berkepribadian utama yang diridhoi oleh Allah.SWT (Ramayulis dan Nizar, 2005). Hal ini sesuai dengan Firman Allah surat At-Tin yang artinya " sesungguhnya kami ciptakan manusia dalam bentuk yang sempurna.

Terkait tentang metode pengajaran, Menurut Mahmud Yunus memaparkan bahwa metode adalah jalan yang akan ditempuh oleh guru untuk memberikan berbagai pelajaran kepada murid-murid dalam berbagai jenis mata pelajaran. Jalan itu adalah khittah (garis) yang direncanakan sebelum masuk ke dalam kelas dan dilaksanakan di dalam kelas waktu mengajar (Ramayulis dan Nizar, 2005). Merode merupakan salah satu unsur terpenting 
dalam proses pembelajaran. Salah satu indikator keberhasilan suatu proses pembelajaran dapat terlihat dari penggunaan metode pembelajaran yang tepat sesuai dengan materi yang diberikan.

Dalam penggunaan metode, Mahmud Yunus menerapkan sistem pengajaran baru yaitu murid-murid belajar siang hari di kelas masing-masing, dan dilanjutkan di malam harinya dia fokus pada pengembangan kreativitas anak. Salah satu contoh penggunaan metode pembelajaran yang diterpkan Mahmud Yunus, ia meminta satu di antara mereka membaca buku bahasa Arab dan yang lain menyimaknya dengan tujuan untuk mengetahui kemampuan dari setiap anak. Kalau dirasa penjelasannya kurang, maka Mahmud Yunus yang menambahkan untuk menjelaskannya lagi. Dengan metode ini murid-murid akan aktif di dalam kelas. Selain itu murid-murid yang belajar kurang lebih 5 sampai 6 tahun akan mampu menggantikan gurunya.

Menurut pandangan Mahmud Yunus, metode pengajaran pendidikan adalah serangkaian cara yang akan ditempuh oleh seorang guru dalam menyampaikan pelajaran kepada murid-murid pada berbagai jenis mata pelajaran. Jalan atau cara ini adalah garisgaris yang direncanakan sebelum masuk ke dalam kelas dan dilaksanakan dalam waktu belajar mengajar di kelas (Yunus, 1990). Disamping itu dalam pandangan Mahmud Yunus metode lebih penting dari pada aspek lainnya. Sebab dalam kenyataan banyak guru yang cukup menguasai materi pelajaran tetapi tidak bisa mentransferkan materi tersebut kepada anak didik karena peserta didik tidak dapat menggunakan metode pembelajaran yang tepat dalam proses kegiatan belajar mengajar. Metode pengajaran merupakan salah satu seni yang terpenting dalam proses pentransferan pengetahuan.

Selain itu, penerapan metode pada suatu mata pelajaran Mahmud Yunus sangat memperhatikan kepada unsur psikologis murid sesuai pula dengan kaidah-kaidah pengajaran modern yaitu perbuatan dengan contoh suri tauladan yang baik (Yunus, 1990). Karena guru harus mampu mengidentifikasi perbedaan masing-masing setiap peserta didiknya. Dengan mengatahui psikis peserta didik yang diajar, guru dapat mendesain metode apa yang tepat untuk diterapkan dikelas yang heterogen peserta didiknya. Dari kalimat tersebut sangat jelas bahwa konsep pemikiran Mahmud Yunus yang 
disosialisasikan benar-benar komperhensif, sehingga menyangkup aspek kognitif, aktif, serta aspek psikomotorik.

Aspek kognitif dapat menjadikan murid selalu berfikir yang rasional, dan kritis dalam menerima dan memahami pelajaran. Menurut Mahmud Yunus aspek afektif membantu murid untuk memahami, menghayati, dan meneladani nilai-nilai moral yang ditanamkan oleh guru kepada murid, dan konsep ini akan berjalan dengan baik apabila dibarengi dengan sikap keteladanan guru dalam berkomunikasi kepada murid dikehidupan seharihari, sedangkan aspek psikomotoriknya dapat membantu murid lebih terarah kepada perkembangan potensi dirinya, dan langsung dapat mengamalkan pengetahuan yang dimilikinya.

Metode dan sistem pendidikan yang dilakukan Mahmud Yunus di atas merupakan perubahan yang sangat drastis terutama dengan dimasukannya pelajaran-pelajaran umum dalam kurikulum seperti praktikum IPA (fisika, kima dan biologi) serta dijadikannya bahasa Arab sebagai bahasa pengantar bahasa sehari-hari. Begitu juga dengan bahasa Inggris dan bahasa Belanda sehingga terciptalah suasana yang sangat ilmiah dan edukatif di kedua lembaga pendidikan Jam'iyah Al Islamiyah dan Normal Islam.

Mahmud yunus menerangkan beberapa kaidah mengajar diantaranya, pentingnya langkah appersepsi (mengulang) ketika memulai suatu kegiatan dalam kelas di antaranya seperti mengaitkan materi sebelumnya dengan materi yang akan disampaikan hari ini, menumbuhkan motivasi peserta didik dengan menampilkan atau menceritakan tokoh-tokoh yang motivator yang dapat dijadikan sebagai inspirasi dan dapat meningkatkan motivasi belajar siswa, menumbuhkan minat belajar siswa dalam pengaktifan panca indra mereka baik dengan lisan, tulisan, perbuatan, maupun dengan alat peraga lainnya, setelah membahas pelajaran baru dan sedikit mengulang-ngulang pelajaran yang lama ini cara itu mengasah siswa dalam berfikir, dan memecahkan masalah, dan menguasai pelajaran yang diberikan (Yunus, 1990)

Pada saat kegiatan belajar mengajar, Mahmud Yunus menyarankan agar guru mendesain dan berkreasi dalam mengelola kelas, sehingga tercipta suasana kelas yang bervariatif di mana Ia menyarankan agar guru ketika mengajar itu berada di tengah-tengah peserta didik. Dengan posisi yang demikian diharapkan peserta didik dan guru dapat 
berinteraksi dengan mereka penuh kasih sayang. Tercipta dialog antara sesama peserta didik, adanya diskusi dan guru dapat mengamati secara langsung kegiatan dan aktivitas peserta didik saat pembelajaran. Guru mengetahui kehidupan keseharian mereka, kecenderungan potensi yang dimilikinya, minat murid, serta bahkan dan kemampuannya. Penyajian pelajaran pun harus disesuaikan dengan waktu dan suasana dengan metode yang bervariasi, yakni seputar metode tanya jawab, metode diskusi, dan diselingi dengan metode-metode lainnya (Yunus, 1990).

Sehubungan dengan metode pengajaran yang efektif dan efesien Mahmud Yunus mengemukakan beberapa asas atau kaedah umum metode pengajaran. Asas-asas tersebut dapat dirinci sebagaimana berikut :

a. Membatasi tujuan pembelajaran, jika sekiranya tujuan dari pembelajaran dianggap terlalu banyak kompetensi yang harus peserta didik kuasai, maka guru harus membatasi tujuan pembelajarannya. Guru harus memikirkan dan memilih metode yeng tepat agar dapat mempermudah dalam pencapaian tujuan pengajaran.

b. Penguasaan bahan serta metodenya. Peserta didik harus menguasai konsep materi pelajaran yang akan disampaikan kepada peserta didik. Guru harus cerdik dalam menyusun dan mendesain bahan pengajaran secara menarik dan inovatif agar proses penyampaian materi dapat diberikan secara maksimal. Hal ini perlu diperhatikan mulai dari pembukaan dalam proses pembelajaran, kegiatan inti dalam penyemapaian materi dan penutup dalam sebuah kegiatan belajar mengajar sehingga materi yang telah disediakan dapat disampaikan dengan efektif pada waktu yang tersedia.

c. Apersepsi, yaitu pendidik harus bias menghubungkan, mengaitkan materi pelajaran sebelumnya dengan materi pelajaran baru yang ingin disampaikan agar peserta didik dapat menerima dan mengaitkan materi secara maksimal.

d. Fokus pada pemilihan metode pembelajaran di mana dalam memilih metode dapat menciptakan suasana belajar yang kondusif dan menarik perhatian dan minat murid.

e. Memanfaatkan panca indera. Seorang pendidik harus bisa memahami dan mengetahui gaya belajar dari peserta didik yaitu dengan memanfaatkan panca indera peserta didik, karena dengan panca indera itu merupakan pintu masuknya suatu pengetahuan. 
f. Mengikutsertakan murid dalam pelajaran, di mana dalam proses kegiatan belajar mengajar guru harus melibatkan peserta didik dalam pembelajaran, terciptanya interasi antara pendidik dan peserta didik agar terbangunnya pembelajaran aktif, dapat menciptakan cara belajar siswa aktif dan memfungsikan guru sebagai fasilitator.

g. Dalam menyusun materi pelajaran, guru harus bisa mengaitkan dan membawa alur pemikiran dari hal-hal yang kongkrit lalu hal-hal yang abstrak.

h. Menyusun pelajaran secara sistematis di mana alur pemikiran diajarakan dari materi yang mudah terlebih dahulu menuju materi yang sulit..

Dan pemaparan di atas, terlihat dengan jelas bahwa metode yang efektif dan efesien itu adalah aspek yang perlu dijadikan sebagai salah satu aspek terpenting dalam pembelajaran di mana harus memperhatikan aspek tujuan, sifat, materi, kecenderungan anak, fasilitas yang tersedia, dan waktu yang ada. Di sini bukan berarti bahwa metode yang efektif dan efesien itu hanya satu, melainkan banyak yang bervariasi. Memaksimalkan metode pembelajaran dengan memaksimalkan bahan ajar dan materi pelajaran sehingga proses penyampaian materi dapat diberikan secara maksimal, guru harus bisa memilih metode yang paling mungkin untuk dilakukan dengan berbagai pertimbangan untuk tercapainya keberhasilan murid dalam berbagai sudut aspeknya, yakni aspek kognitif, aspek afektif, dan aspek psikomotorik.

Mahmud Yunus menganjurkan agar setiap pelajaran yang disajikan dapat disesuaikan dengan waktu dan suasana serta menggunakan metode yang bervariasi. Alokasi waktu merupakan salah tolak ukur guru dalam kegiatan belajar mengajar, di mana dengan adanya waktu, guru dapat mengatur hal-hal yang harus disampaikan dalam pembelajaran.

\section{KESIMPULAN}

Mahmud Yunus berusaha merefleksikan keseimbangan ilmu agama dan ilmu umum yang selama ini belum dikenal di madrasah tradisional. Di dalam kurikulum pendidikan Mahmud Yunus menerapkan beberapa metode pengajaran bahasa Arab yang memadukan antara unsur membaca, menulis, memahami, dan berbicara dengan menggunakan bahasa Arab. Mahmud Yunus melihat kurikulum pengajaran sebagai unsur penting dalam 
pengajaran dan Mahmud Yunus mengatakan bahwa kurikulum pengajaran adalah hal yang penting dalam ungkapan al-thariqah ahammu min al-maddah.

Untuk mencapai tujuan pendidikan itu dengan baik, maka seorang guru harus memperhatikan materi dan metode yang dipilihnya karena menurut Mahmud Yunus metode itu lebih penting daripada materi. Maka dalam menerapkan metode hendaklah seorang guru memilih melihat dan memperhatikan sifat, dan usia perkembangan anak didik serta alat yang akan digunakan. Metode yang di terapkan Mahmud Yunus ialah metode ceramah, tanya jawab (dialog), pemberian tugas, demonstrasi, kerja kelompok, dan metode uswatun hasanah (keteladanan).

Kelembagaan pendidikan yang dikembangkan dan dipimpin Mahmud yunus itu mencoba memadukan antara sekolah Belanda dan perkembangan pada waktu itu dan menerapkan pendidikan yang telah Mahmud Yunus dapatkan selama menuntut ilmu di Mesir yaitu dengan adanya perjenjangan pendidikan dan program pendidikan yang berlangsung selama dua belas tahun seperti ibtidaiyah 4 tahun tsanawiyah 4 tahun dan aliyah 4 tahun.

Konsep pendidikan Mahmud Yunus tidak terlepas dari pemahaman mengenai konsep pendidikan Islam itu sendiri. Tujuan pendidikan yang di terapkan oleh Mahmud Yunus adalah menjadikan peserta didik yang beriman kepada Allah SWT dan mampu melaksanakan semua pekerjaan keduniaan dan urusan agama secara serasi dan seimbang. Mahmud Yunus beranggapan bahwa tujuan pendidikan yang paling penting adalah menjadikan anak didik yang berakhlak, oleh karena itu materi pendidikan yang dikembangkan oleh Mahmud Yunus itu tidak hanya sebatas tentang pengetahuan agama semata tetapi ilmu pengetahuan umum juga diajarkan.

\section{DAFTAR PUSTAKA}

Arifin, M. M.ed. 2006. Ilmu Pendidikan Islam. Jakarta: Bumi Aksara.

Arief, Armai. Mahmud Yunus dan Pemikiran Pendidikan Islam di Indonesia

Assegaf, Abd.Rachman. 2010. Pendidikan Islam Konstektual. Yogyakarta: Pustaka Pelajar. 
Fahdini, et.al. Identifikasi Kompetensi Guru sebagai Cerminan Profesionalisme Tenaga Pendidik di Kabupaten Sumedang. Jurnal Mimbar Sekolah Dasar, 1 (1), 33-42. Retrieved from https://ejournal.upi.edu/index.php/mimbar/article/view/1362/952

Mujib, Abdul dan Jusuf Mudzakkir. 2006. Ilmu Pendidikan Islam. Jakarta: Kencana Predana Media.

Manti, et.al. 2016. Konsep Pendidikan Modern Mahmud Yunus dan Kontribusinya bagi Lembaga Pendidikan Islam di Indonesia. Ta'dibuna International Journal of Islamic Education, 5 (2), 151-183. Retrieved from http://ejournal.uikabogor.ac.id/index.php/TADIBUNA/article/view/589/820

Masyhudi, Fauza. 2014. Pemikiran Mahmud Yunus tentang Konsep Pendidikan Islam. $\begin{array}{llllll}\text { Jurnal } & \text { Tarbiyah, } & 21 & \text { (1), } & \text { 96-118. } & \text { Retrieved from }\end{array}$ http://jurnaltarbiyah.uinsu.ac.id/index.php/tarbiyah/article/view/220/197

Nata, Abuddin. 2005. Tokoh-Tokoh Pembaharuan Pendidikan Islam. Jakarta: Raja Grafindo.

Pujiastuti, Eko, et.al. 2012. Kompetensi Profesional, Pedagogik Guru IPA, Persepsi Siswa Tentang Proses Pembelajaran, dan Kontribusinya terhadap Hasil Belajar IPA Di SMP/Mts Kota Banjarbaru. Innovative Journal of Curriculum and Educational $\begin{array}{llllll}\text { Technology } & 1 & (1), & 22-29 . & \text { Retrieved } & \text { from }\end{array}$ http://journal.unnes.ac.id/sju/index.php/ujet

Ramayulis, Samsul Nizar. 2005. Ensiklopedi Tokoh Pendidikan Islam. Ciputat: Quantum Teaching.

Safiq, Abdulloh dan Umi Salamah. 2019. Relevansi Pemikiran Mahmud Yunus dalam Kitab At-Tarbiyah wa At-Ta'lim dengan Kompetensi Guru (Undang-Undang Nomor 14 Tahun 2005). Al-Mudarris: Journal of Education, 2 (2), 224-243. Retrieved from http://e-journal.staima-alhikam.ac.id/index.php/almudarris/article/view/287/pdf_1

Suhartono. 1994. Sejarah Pergerakan Nasional dari Budi Utomo sampai Proklamasi 19081945. Yogyakarta: Pusaka Pelajar.

Tafsir, Ahmad. 2009. Ilmu Pendidikan Islam di Minangkabau. Jakarta: Suara Abi. 
Undang - undang RI.Nomor 20 Tahun 2003 Tentang SISDIKNAS dan Peraturan Pemerintah R.I. Tahun 2010 Tentang Penyelenggaraan Pendidikan serta Wajib Belajar. Bandung: Citra Umbara.

Wahab, Rochidin. 2004. Sejarah Pendidikan Islam di Indonesia. Bandung: Alfabeta.

Yunus, Mahmud. 1990. Sejarah Pendidikan Islam. Jakarta : PT Hidakarya Agung.

Yunus, Mahmud. 1996. Sejarah Pendidikan Islam di Indonesia. Jakarta: PT Hidakarya Agung.

Yunus, Mahmud. 1992. Metodik Khusus Pendidikan Agama. Jakarta: PT Hidakarya Agung.

Yunus, Mahmud dan Kasim Bakri. 1986. Attarbiyah wa ta'liem. Gontor Ponorogo.

Yunus, Mahmud. 1978. Pokok-Pokok Pendidikan dan Pengajaran. PT Hidakarya Agung 